\title{
Expression and uptake of the thyroxine-binding protein transthyretin is regulated by oxygen in primary trophoblast placental cells
}

\author{
J Patel ${ }^{1,2}$, K A Landers², R H Mortimer ${ }^{1,2,3}$ and K Richard ${ }^{1,2}$ \\ ${ }^{1}$ School of Medicine, Royal Brisbane and Women's Hospital, The University of Queensland, Herston, Brisbane, Queensland 4029, Australia \\ ${ }^{2}$ Conjoint Endocrine Laboratory, Pathology Queensland and Department of Endocrinology, Royal Brisbane and Women's Hospital, QIMR Bancroft Centre, \\ Herston, Brisbane, Queensland 4029, Australia \\ ${ }^{3}$ Disciplines of Medicine, Obstetrics and Gynaecology, The University of Queensland, Herston, Brisbane, Queensland 4029, Australia \\ (Correspondence should be addressed to K Richard at Conjoint Endocrine Laboratory, Pathology Queensland and Department of Endocrinology, Royal Brisbane \\ and Women's Hospital; Email: kerry.richard@qimr.edu.au)
}

\begin{abstract}
Transplacental delivery of maternal thyroid hormones to the fetus, in particular thyroxine $\left(\mathrm{T}_{4}\right)$, is critical in ensuring normal fetal neurological development. The fetus relies on maternal $\mathrm{T}_{4}$ till around 16 weeks gestation, but mechanisms of placental $\mathrm{T}_{4}$ transport are not yet fully elucidated. Placenta produces, secretes and takes up the thyroid hormone-binding protein transthyretin (TTR). Many placental genes are regulated by oxygen levels, which are relatively low (1\%) in the early first trimester, rising to $3 \%$ in the mid first trimester and $8 \%$ in the early second trimester and thereafter. We examined the expression and uptake of TTR in isolated primary human placental cytotrophoblast cells cultured under different oxygen concentrations $\left(1,3,8,21 \% \mathrm{O}_{2}\right.$ and $200 \mu \mathrm{M}$ desferrioxamine (DFO)) for $24 \mathrm{~h}$. We observed sevenfold
\end{abstract}

higher expression of TTR mRNA and protein levels at $1 \% \mathrm{O}_{2}$ than at 8 and $21 \% \mathrm{O}_{2}$. Significant increases were observed after culture at $3 \% \mathrm{O}_{2}$ and following DFO treatment. We observed significantly higher uptake of ${ }^{125} \mathrm{I}$-TTR and Alexa594-TTR when cells were cultured at 1 and $3 \% \mathrm{O}_{2}$ and in the presence of $200 \mu \mathrm{M}$ DFO than at 8 and $21 \% \mathrm{O}_{2}$. When JEG-3 choriocarcinoma cells were transfected with TTR promoter reporter constructs, increased luciferase activity was measured in cells cultured at 1 and $3 \% \mathrm{O}_{2}$ in comparison to 8 and $21 \% \mathrm{O}_{2}$. We conclude that placental TTR expression and uptake is increased by the relative hypoxia observed in the first trimester of pregnancy, a time when materno-fetal $\mathrm{T}_{4}$ transfer is the sole source of fetal $\mathrm{T}_{4}$.

Journal of Endocrinology (2012) 212, 159-167

\section{Introduction}

Thyroid hormone, in particular thyroxine $\left(\mathrm{T}_{4}\right)$, plays an important role in the activation, differentiation and maturation of the fetal central nervous system (Bernal 2005, Patel et al. 2011b). Before 16 weeks gestation, the fetus relies solely on transplacental delivery of maternal $\mathrm{T}_{4}$ (Obregon et al. 2007). By 6 weeks gestation, measurable amounts of $T_{4}$ and $\mathrm{T}_{3}$ have been detected in human fetal coelomic fluid and there is evidence to suggest that even after the onset of fetal thyroid function, transport of $\mathrm{T}_{4}$ from maternal to fetal circulation continues (Vulsma et al. 1989, Patel et al. 2011a). Rat experiments suggest that fetal brain development preferentially requires $T_{4}$, which is locally deiodinated to $T_{3}$ (Calvo et al. 1990). Clinical studies suggest that even mild reductions in maternal $T_{4}$ adversely affect the intellectual function of offspring, indicating that human brain development is very sensitive to mild maternal hypothyroidism (Haddow et al. 1999). The biological corollary of these clinical and animal studies is that a maternal to fetal $\mathrm{T}_{4}$ transfer system must operate in very early human pregnancy. Some of the components of this putative system and its possible regulation (trophoblast cell membrane thyroid hormone transporters, placental type III deiodinase and possibly transthyretin (TTR)) are known but the mechanisms of thyroid hormone transfer and its regulation are yet to be elucidated (Patel et al. 2010a).

We have recently reported that human trophoblast cells produce the $\mathrm{T}_{4}$ and retinol-binding protein, TTR (McKinnon et al. 2005). Studies on polarised choriocarcinoma JEG-3 cells maintained in bicameral chambers indicate that TTR is secreted apically and basally (Landers et al. 2009). Trophoblasts also take up TTR from culture medium and this uptake is increased when $T_{4}$ is bound to TTR, increasing TTR tetramer formation (Landers et al. 2009). These findings raise the possibility that placental TTR is involved in a transplacental $\mathrm{T}_{4}$ shuttle system.

The early placenta is marked by low oxygen levels (1\%) that increase as placental vascularisation is established so that by 12 weeks gestation placental oxygen levels reach $8 \%$, a concentration that in normal pregnancies is maintained until term (Schneider 2011). Many placental genes and placental 
development itself are regulated by changing oxygen levels throughout gestation (Patel et al. 2010b). We have recently demonstrated in JEG-3 cells that TTR mRNA expression, protein levels and uptake are increased at the lower oxygen levels found in the early placenta (Patel et al. 2010a).

Therefore, the aim of this study was to investigate the TTR expression and uptake by isolated human term trophoblasts cultured under different oxygen concentrations reported in the developing human placenta to confirm our previous findings in JEG-3 cells. We also measured TTR promoter activity in JEG-3 cells cultured under different oxygen concentrations. We postulate that TTR expression and uptake in primary trophoblast cells will increase at low oxygen levels, as suggested by our previous work on JEG-3 cells.

\section{Methods and Materials}

\section{Placental tissue}

Placentas from term (38-39 weeks; $n=12)$ normal healthy women undergoing caesarean section at the Royal Brisbane and Women's Hospital were collected, with informed consent, soon after delivery. This study was approved by the Royal Brisbane and Women's Hospital and Queensland Institute of Medical Research Human Research Ethics Committees.

\section{Isolation of cytotrophoblast cells from placental tissue}

Villous cytotrophoblasts were isolated as described previously (Kliman et al. 1986, Greenwood et al. 1996, Barber et al. 2005). Isolated cytotrophoblasts were cultured in DMEM:F12 nutrient mixture, $25 \mathrm{mM}$ HEPES and 1\% L-glutamine (all from Sigma), supplemented with 1\% penicillin/streptomycin, $0 \cdot 1 \%$ plasmocin and 10\% FCS (all from Invitrogen). Cytotrophoblasts were seeded onto sterile coverslips in 24-well culture plates and fixed for immunocytochemical staining of cytokeratin-7 to determine purity of the cell population.

\section{Low oxygen experiments}

Isolated cytotrophoblasts were simultaneously seeded at $3 \times$ $10^{6}$ cells in a 6-well culture plate and cultured for 4 days. From days 1 to 3 , the cells were grown under standard laboratory culture conditions at $21 \% \mathrm{O}_{2}$. On day 3 , the cells were transferred to Heraeus HeraCell incubators (Thermo Scientific, Langenselbold, Germany) and maintained at different oxygen concentrations of 1,3 and $8 \%$ for $24 \mathrm{~h}$. Cells were also studied at $21 \% \mathrm{O}_{2}$, which is standard laboratory practice and routine for placental cell function studies. Desferrioxamine (DFO; $200 \mu \mathrm{M})$, a hypoxic mimetic drug, was used as a positive control (Li et al. 2011). DFO, a hypoxia mimetic drug, was used in this study as a positive control and has been used in JEG-3 cells in other studies at similar concentrations without affecting cell viability (Patel et al. 2010a). DFO is an iron chelator and mimics hypoxia by inhibiting prolyl hydroxylases, which are essential for the proteasomal degradation of hypoxia-inducible factor- $1 \alpha$ (HIF-1 $\alpha$ ) during times of normoxia $\left(>5 \% \mathrm{O}_{2}\right)$, resulting in the nuclear accumulation of HIF- $1 \alpha$ and downstream effects (Ran et al. 2005). DFO has been used extensively in many cell and tissue types and is recognised as the gold standard for creating a hypoxic environment under normoxic conditions (Ran et al. 2005, Takeda et al. 2007, Chu et al. 2010). Viability of cells used in the experiment was assessed on day 4 by measurement of human chorionic gonadotrophin (hCG) and lactate dehydrogenase (LDH) in cell culture medium. hCG is a marker of trophoblast function and LDH secretion is elevated when cellular material breaks down. hCG and LDH were measured by Chemical Pathology, Pathology Queensland. hCG was measured using the Beckman Coulter Access Immunoassay Total $\beta$ hCG system (intra-assay coefficient of variation (CV) $4 \cdot 1 \%$; inter-assay $\mathrm{CV} 4 \cdot 6 \%$ ). $\mathrm{LDH}$ was measured using the Beckman Coulter SYNCHRON LX system with the SYNCHRON enzyme validator set (intraassay CV $3 \cdot 5 \%$; inter-assay CV 7.3\%).

\section{Quantitative RT-PCR}

On day 4, following $24 \mathrm{~h}$ of culture at low oxygen or treatment with DFO, total RNA was extracted from the trophoblast cells using the RNAeasy Mini Kit (Qiagen). Total RNA $(4 \mu \mathrm{g})$ was reverse transcribed to produce cDNA using the Superscript III RT Kit (Invitrogen) and $\mathrm{P}(\mathrm{dt})_{15}$ primers (Roche Applied Sciences) in a reaction volume of $20 \mu \mathrm{l}$. Quantitative PCR was performed using $0.5 \mu \mathrm{M}$ of forward and reverse primers with FastStart SYBR Green master-mix in a $15 \mu \mathrm{l}$ reaction, which included $3 \mu \mathrm{l}$ cDNA (Roche Applied Sciences) in a Rotor Gene RG-3000 (Corbett Research, Sydney, NSW, Australia). The real-time PCR method was validated by using serially diluted cDNA as a standard curve. To quantify the mRNA expression profile in each sample, the efficiency of each standard curve was determined by its slope and comparative threshold according to the manufacturer's instructions. For each sample, the amount of targeted mRNA (AU) was normalised to the housekeeping gene $\beta$-actin. mRNA quantification was performed using the Pfaffl method (Pfaffl et al. 2002), which makes no distributional assumptions. The primers used to amplify specific mRNAs are listed in Table 1 .

Table 1 Primer sequences

$\begin{array}{ll}\text { Gene } & \text { Primers } \\ \beta \text {-Actin } & \begin{array}{l}\text { (Forward) 5'-CATGTACGTTGCTATCCAGGC-3' } \\ \text { (Reverse) 5'-CTCCTTAATGTCSCGCACGAT-3' } \\ \text { TTR }\end{array} \\ \begin{array}{l}\text { (Forward) 5'-ATGGCTTCTCATCGTCTGCT-3' } \\ \text { (Reverse) 5'-TGTCATCAGCAGCCTTTCTG-3' }\end{array}\end{array}$

TTR, transthyretin. 
All PCR samples were run from three separate cell culture experiments in triplicate. Data from each experiment were averaged and then compared to values obtained from cells cultured at $8 \% \mathrm{O}_{2}$ to determine fold changes in expression and S.E.M. These data were used to carry out statistical analysis.

\section{Western blotting}

On day 4 , following $24 \mathrm{~h}$ of culture at low oxygen or DFO treatment, protein was extracted from the trophoblast cells using the M-PER Mammalian Protein Extraction Reagent (Thermo Scientific, Rockford, IL, USA) and Protein Inhibitor Cocktail (Sigma). HIF-1 $\alpha$ westerns were performed on nuclear extracts prepared using a NE-PER Nuclear Extraction Kit (Thermo Scientific). Total protein $(30 \mu \mathrm{g})$ was separated on 4-12\% Novex NuPage Bis/Tris gels (Invitrogen) and transferred onto nitrocellulose membrane (Bio-Rad Trans-Blot). Rabbit anti-TTR (Dako Australia Pty Ltd, Campbellfield, VIC, Australia), mouse anti-HIF-1 $\alpha$ (Abcam) and mouse anti- $\beta$-actin (Sigma) antibodies were used at 1:1000 dilutions. HRP-conjugated secondary antibodies (GE Healthcare, Buckinghamshire, UK) were used at 1:3000. Blots were developed using a Supersignal West Femto Kit (Pierce Biotechnology, Rockford, IL, USA) following the manufacturer's instructions and images captured by chargecoupled device camera (Fuji image LAS-3000; FujiFilm, Brookvale, NSW, Australia). Densitometric analysis was performed using Multigauge v2.3 Software (Fuji, FujiFilm). Each experiment was carried out in triplicate.

\section{Brefeldin A treatment}

On day 3, isolated trophoblast cells grown in 6-well cell culture flasks were incubated overnight in serum-free (SF) media. On day 4, the cells were then cultured in SF media $\pm 10 \mu \mathrm{g} / \mathrm{ml}$ brefeldin A for $6 \mathrm{~h}$. Brefeldin A inhibits the transport of proteins from the endoplasmic reticulum (ER) to the Golgi apparatus, leading to the accumulation of protein with the ER, preventing secretory proteins such as TTR from being released (Klausner et al. 1992). SF media was used since serum contains TTR and other proteins that may interfere with the experiment. Total cell lysates were collected and analysed by western blotting, with each experiment carried out in triplicate. Brefeldin A had no adverse effects on cell viability as determined by trypan blue exclusion. This experiment was carried out under the same oxygen conditions as described previously.

\section{TTR labelling}

TTR (Sigma) was labelled with ${ }^{125}$-Iodine $\left({ }^{125} \mathrm{I}\right)$ using the chloramine-T method by John Bellen, Department of Nuclear Medicine, Royal Brisbane and Women's Hospital (Greenwood et al. 1963). Fluorescent labelling of TTR (Alexa-TTR) was performed with an Alexa-Fluor-594
Labelling Kit according to the manufacturer's instructions (Invitrogen).

\section{${ }^{125}$ I-TTR membrane binding and internalisation}

On day 3, isolated trophoblast cells were transferred to 1, 3, 8, or $21 \mathrm{O}_{2} \pm 200 \mu \mathrm{M}$ DFO for $24 \mathrm{~h}$ in 6-well plates prior to uptake studies on day 4; each experiment was carried out in triplicate. Binding and internalisation studies were performed as described previously (Landers et al. 2009). Cells were washed with PBS and cultured in SF-DMEM for $4 \mathrm{~h}$ before incubation with ${ }^{125}$ I-TTR $(10 \mathrm{pM})$ in SF-DMEM containing $100 \mu \mathrm{M}$ potassium perchlorate at $37^{\circ} \mathrm{C}$. Incubation with an excess of unlabelled TTR $(1 \mu \mathrm{M})$ was used to distinguish between specific/non-specific binding and internalisation. $\mathrm{T}_{4}(10 \mu \mathrm{M})$ was used as described previously (Landers et al. 2009). Cells were incubated in a $21 \% \mathrm{O}_{2}$ incubator for $1 \mathrm{~h}$ to allow binding and internalisation to occur. After $1 \mathrm{~h}$, the media was removed and cells washed in ice-cold PBS. Surface bound proteins were removed using ice-cold $0.025 \%$ trypsin $/ 0 \cdot 01 \%$ EDTA as described previously (Divino \& Schussler 1990, Landers et al. 2009). Internalised TTR was collected by harvesting cells with $1 \mathrm{M}$ $\mathrm{NaOH}$ for $5 \mathrm{~min}$ at $37^{\circ} \mathrm{C}$. Samples were counted in a Packard Cobra II series counter (Hewlett Packard, Blackburn, VIC, Australia), with a counting efficiency of $80 \cdot 27 \%$.

\section{Alexa-TTR internalisation}

On day 3, isolated cytotrophoblast cells were transferred to SF-DMEM for $16 \mathrm{~h}$ before incubating the cells with $100 \mu \mathrm{g} / \mathrm{ml}$ Alexa594-TTR for $1 \mathrm{~h}$. Uptake of Alexa-TTR was evaluated in the presence of $1 \mu \mathrm{M}$ unlabelled TTR and $10 \mu \mathrm{M} \mathrm{T}_{4}$ (Landers et al. 2009). Cells were washed with cold PBS before fixation in 4\% paraformaldehyde. Counterstaining with DAPI and phalloidin were conducted to mark nuclei and actin filaments respectively. Images were captured using Deltavision Core Technology (Applied Precision, Washington, DC, USA). To ensure identical image analysis for the comparison of TTR uptake was undertaken, all slides from the same experiment were scanned using the same settings including u.v. light transmission and exposure time. Captured images were displayed with the same intensity scale for channel of Alexa-Fluor594 labelled TTR. Using ImageJ Software (National Institutes of Health, NIH), individual cells $(n=30)$ were randomly selected, magnified and the intracellular TTR-labelled foci (red) counted.

\section{Preparation of TTR promoter constructs}

Upstream regions $(0 \cdot 11,0.65$ and $2 \cdot 1 \mathrm{~kb})$ of the human TTR gene (Mirkovitch \& Darnell 1991) were ligated into the $p$ GL3-basic vector between the KpnI and NheI sites (Promega). The following primers were used: $0 \cdot 11 \mathrm{~kb}$ (5'-GGCGGTACCTTGACTAAGTCAATA-3'), $\quad 0 \cdot 65 \mathrm{~kb}$ (5'-GGCGGTACCGAGAAATTGCTGACTAAGCAA-3') 

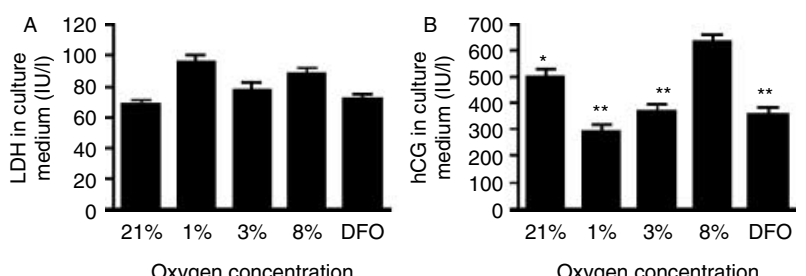

Figure 1 hCG and LDH levels in cell culture medium from primary cytotrophoblast cells cultured at different oxygen concentrations $\left(1,3,8\right.$ and $\left.21 \% \mathrm{O}_{2}\right)$ and treated with $200 \mu \mathrm{M}$ DFO. (A) LDH levels were not different. (B) Significant increases in hCG secretion were observed from cells cultured at $8 \% \mathrm{O}_{2}$ in comparison to all other groups. All experiments were performed in triplicates. ${ }^{*} P \leq 0.05$ vs $8 \%$; ${ }^{* *} P \leq 0 \cdot 01$ vs $8 \%$.

and $2 \cdot 1 \mathrm{~kb}\left(5^{\prime}\right.$-GGCGGTACCTAACATATCTATGGGCTGATG-3'). The following reverse primer was used for all three sequences $\left(5^{\prime}\right.$-TATCGCTAGCAGGAGCAGACGATGAGAAGC- $\left.3^{\prime}\right)$. The constructs were designated pGL3$0.11 \mathrm{~kb}(0.11 \mathrm{~kb}$ insert $)$, pGL3-0.65 kb (0.65 kb insert) and pGL3-2.1 kb $(2 \cdot 1 \mathrm{~kb}$ insert). The TTR promoter constructs were cloned using JM109 Escherichia coli and the vector (plasmid) DNA was extracted using the Qiagen Plasmid Midi Kit (Qiagen). Quality of plasmid DNA (pDNA) extracted was measured for concentration and purity using A260/A280 spectroscopy on the Nanodrop ND-1000 machine (Thermo Scientific).

\section{Luciferase assays}

JEG-3 cells were obtained from the American Type Culture Collection (ATCC, Manassas, VA, USA) and maintained in DMEM (Sigma) with 1\% penicillin/streptomycin, 0.1\% plasmocin and $10 \%$ fetal bovine serum. Once confluent, JEG-3 cells were plated onto white flat bottom 96-well plates (Perkin Elmer, Glen Waverley, VIC, Australia) with regular culture medium. On day 2, the cells were transfected with a total of $0.33 \mu \mathrm{g}$ pDNA per well. The transfection mixture contained 300 ng empty pGL3 vector or pGL3 containing the TTR promoter insert with $30 \mathrm{ng}$ of the internal control vector (pRL-TK), at a ratio of 3:1 with FuGENE 6 transfection reagent (Roche), according to the manufactures' instructions. Transfection mixture $(100 \mu \mathrm{l})$ was added to each appropriate well. Transfected cells were cultured under the same low oxygen conditions previously described for a further $24 \mathrm{~h}$. The luciferase reporter assay was conducted by using the Promega Dual-Glo Luciferase reporter assay kit (Promega). Luminescence was measured using the POLARstar OPTIMA luminometer (BMG Labtech, Mornington, VIC, Australia). The ratio of firefly:Renilla luminescence for each well $(n=12)$ was calculated.

\section{Statistical analysis}

All data sets were represented as mean \pm s.E.M. Significant differences were determined using ANOVA with Dunnett's multiple comparison post-hoc test using results from experiments conducted at $8 \% \mathrm{O}_{2}$ as the reference level. A $P$ value of $P \leq 0.05$ was considered statistically significant.

\section{Results}

In the analysis of the data, we have focussed on the physiologically relevant oxygen concentrations that are present in vivo during placental development: 1, 3 and $8 \% \mathrm{O}_{2}$.

\section{Cell culture purity and viability}

Trophoblast cell population purity ranged from 90 to $100 \%$, as judged by cytokeratin-7 staining. Cell function and viability were assessed on day 4 of culture by measuring hCG and $\mathrm{LDH}$ concentrations in culture media (Fig. 1). At $8 \% \mathrm{O}_{2}$ $(632.31 \pm 29 \cdot 8 \mathrm{IU} / 1)$, the highest level of secreted hCG was measured in comparison to all other experimental groups: $1 \%$ $(291.51 \pm 24.79 \mathrm{IU} / 1, P \leq 0 \cdot 01), 3 \%(365 \cdot 36 \pm 32.64 \mathrm{IU} / 1$, $P \leq 0 \cdot 01), 21 \%(502 \cdot 64 \pm 26 \cdot 57 \mathrm{IU} / 1 \quad P \leq 0 \cdot 05)$ and $\mathrm{DFO}$ $(352 \cdot 4 \pm 31 \cdot 29, P \leq 0 \cdot 01 \mathrm{IU} / 1)$.

\section{TTR $m R N A$ expression}

RT-PCR results revealed significant differences in TTR mRNA expression in cells cultured under different oxygen concentrations (Fig. 2). At 1 and $3 \% \mathrm{O}_{2}$ and following $200 \mu \mathrm{M}$ DFO treatment, there was a $5 \cdot 54 \pm 0 \cdot 61(P \leq 0 \cdot 001)$, $4 \cdot 84 \pm 0 \cdot 71(P \leq 0 \cdot 001)$ and $4 \cdot 31 \pm 0 \cdot 64(P \leq 0 \cdot 001)$ respective fold increase in TTR mRNA expression in comparison to cells grown at $8 \% \mathrm{O}_{2}$ (Fig. 2). This shows that TTR mRNA levels are up-regulated under hypoxic conditions.

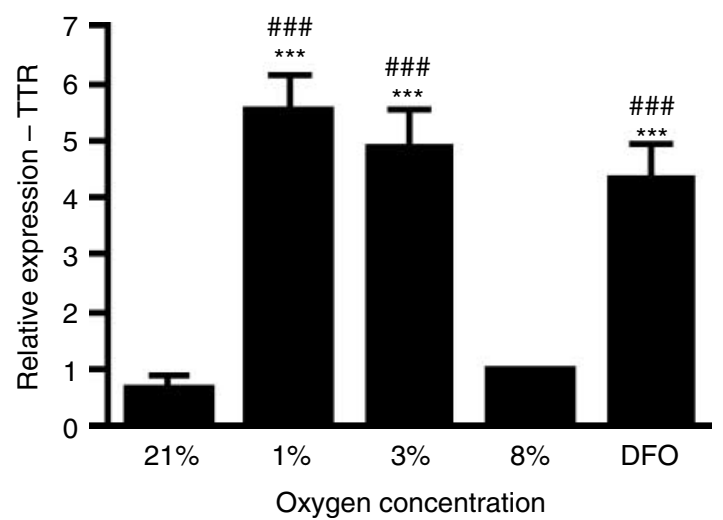

Figure 2 TTR mRNA expression in primary cytotrophoblast cells cultured at different oxygen concentrations $\left(1,3,8\right.$ and $21 \% \mathrm{O}_{2}$ ) and treated with $200 \mu \mathrm{M}$ DFO. All groups were normalised to $8 \% \mathrm{O}_{2}$. Significant fold increases in TTR mRNA were observed at $1 \%(5 \cdot 54 \pm 0 \cdot 61) \mathrm{O}_{2}, 3 \%(4 \cdot 84 \pm 0 \cdot 71) \mathrm{O}_{2}$ and with $200 \mu \mathrm{M}$ of DFO $(4 \cdot 31 \pm 0 \cdot 64)$ in comparison to $8 \% \mathrm{O}_{2}$. Significant increases were also observed at 1 and $3 \% \mathrm{O}_{2}$ and $200 \mu \mathrm{M}$ DFO in comparison to $21 \% \mathrm{O}_{2}$. $\beta$-Actin was used as the housekeeping gene. All experiments were performed in triplicates. ${ }^{* *} P \leq 0 \cdot 001$ vs $8 \% ;{ }^{\# \#} P \leq 0.001$ vs $21 \%$. 


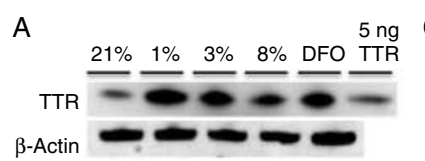

B

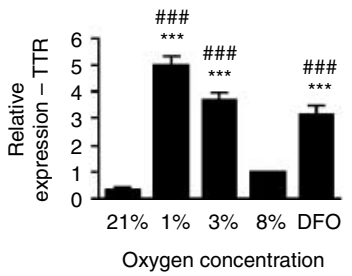

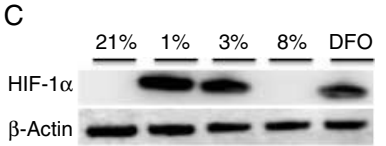

D

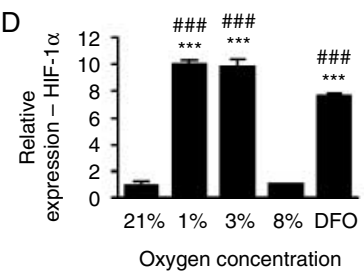

Figure 3 Western blots of TTR and HIF-1 $\alpha$. (A) Western blot demonstrating changes in TTR protein production in cells cultured at different oxygen concentrations $\left(1,3,8\right.$ and $\left.21 \% \mathrm{O}_{2}\right)$ and treated with $200 \mu \mathrm{M}$ DFO. (B) All groups were normalised to $8 \% \mathrm{O}_{2}$.

Significant fold increases in TTR protein expression were observed at $1 \%(4.97 \pm 0.33) \mathrm{O}_{2}, 3 \%(3.64 \pm 0.31) \mathrm{O}_{2}$ and $200 \mu \mathrm{M}$ DFO $(3 \cdot 13 \pm 0 \cdot 36)$ in comparison to $8 \% \mathrm{O}_{2}$. Significant increases were also observed at 1 and $3 \% \mathrm{O}_{2}$ and $200 \mu \mathrm{M}$ DFO in comparison to $21 \% \mathrm{O}_{2}$. (C) and (D) Western blot and densitometry demonstrating the activation of HIF-1 $\alpha$ protein collected from nuclear extracts in cells cultured different oxygen concentrations (1, 3, 8 and $21 \% \mathrm{O}_{2}$ ) and treated with $200 \mu \mathrm{M}$ DFO. $\beta$-Actin was used as the housekeeping gene for both TTR and HIF-1 $\alpha$. All experiments were performed in triplicates. ${ }^{* *} P \leq 0 \cdot 001$ vs $8 \% ;{ }^{\# \#} P \leq 0 \cdot 001$ vs $21 \%$.

\section{TTR protein expression}

It is very difficult to directly measure TTR secreted by cells into culture medium since the concentration of TTR diluted into the medium is below the limits of detection of available assays. To overcome this, cells were incubated with brefeldin A to prevent active secretion of TTR into the culture medium, therefore allowing cellular TTR protein to accumulate sufficiently to be measured. In cells cultured at 1 and $3 \% \mathrm{O}_{2}$ and following $200 \mu \mathrm{M}$ DFO treatment, there were $4 \cdot 97 \pm 0 \cdot 33(P \leq 0 \cdot 001), 3 \cdot 64 \pm 0 \cdot 31(P \leq 0 \cdot 001)$ and $3 \cdot 13 \pm 0 \cdot 36(P \leq 0 \cdot 001)$ fold increases, respectively, in TTR protein expression in comparison to cells cultured at $8 \% \mathrm{O}_{2}$ (Fig. 3).

The effects of intracellular hypoxia were assessed by measurement of trophoblast HIF-1 $1 \alpha$ levels. In comparison to cells cultured at $8 \% \mathrm{O}_{2}, \mathrm{HIF}-1 \alpha$ protein showed fold increases of $9.97 \pm 0.34(P \leq 0.001)$ from cells cultured at $1 \% \mathrm{O}_{2}, 9 \cdot 76 \pm 0 \cdot 65(P \leq 0 \cdot 001)$ at $3 \% \mathrm{O}_{2}$ and $7 \cdot 61 \pm 0 \cdot 29$ with $200 \mu \mathrm{M}$ DFO treatment. This clearly demonstrates a functioning in vitro hypoxia model (Fig. 3).

\section{${ }^{125}$ I-TTR and Alexa-Fluor594-TTR uptake}

Effect of $\mathrm{T}_{4}$ binding on TTR internalisation by trophoblast cells was determined using ${ }^{125}$ I-TTR uptake assays. ${ }^{125} \mathrm{I}-$ TTR uptake was measured in the presence and absence of $1 \mu \mathrm{M}$ TTR and $10 \mu \mathrm{M} \mathrm{T}$. Significant increases in ${ }^{125} \mathrm{I}$-TTR uptake were measured in cells cultured at $1 \% \quad \mathrm{O}_{2}$ in comparison to $8 \% \mathrm{O}_{2}(1 \cdot 85$-fold increase $P \leq 0 \cdot 01)$. Increases in TTR uptake in cells cultured at $3 \% \mathrm{O}_{2}(1 \cdot 56$-fold increase,

$P \leq 0 \cdot 01)$ and following $200 \mu \mathrm{M}$ DFO treatment $(1 \cdot 58$-fold increase, $P \leq 0.01)$ were also observed in comparison to cells cultured at $8 \% \mathrm{O}_{2}$ (Fig. 4).

Internalisation of Alexa594-TTR by trophoblast cells was visualised as small red foci bordered by phalloidin (green)stained actin filaments. Alexa594-TTR uptake was increased in cells cultured at 1 and $3 \% \mathrm{O}_{2}$ and following $200 \mu \mathrm{M} \mathrm{DFO}$ treatment in comparison to $8 \% \mathrm{O}_{2}$ (Fig. 5A). Using Image J software, individual intracellular TTR foci were counted. Significant increases in intracellular TTR foci were counted in cells that had been cultured at $1 \% \quad \mathrm{O}_{2} \quad(12 \cdot 9 \pm 0 \cdot 8$, $P \leq 0 \cdot 001), 3 \% \mathrm{O}_{2}(11 \cdot 8 \pm 1 \cdot 1, P \leq 0 \cdot 001)$ and following DFO treatment $(9.90 \pm 0.50, P \leq 0.01)$ in comparison to $8 \% \mathrm{O}_{2}$ (Fig. 5B).

\section{TTR promoter activity}

TTR promoter activity was measured via luciferase production following transfection of reporter constructs into JEG-3 placental cells and cultured under low oxygen conditions (Fig. 6). No significant differences in luciferase activity were measured between experimental groups in JEG-3 cells transfected with the pGL3-0.11 kb TTR promoter construct. A significant increase in luciferase activity was observed in JEG-3 cells transfected with the pGL3$0.65 \mathrm{~kb}$ TTR promoter construct cultured at $1 \% \mathrm{O}_{2}$ in comparison to $8 \%(P \leq 0 \cdot 01)$ and $21 \% \quad \mathrm{O}_{2} \quad(P \leq 0 \cdot 01)$. Significant increases were also observed in cells cultured at $3 \% \mathrm{O}_{2}$ and $200 \mu \mathrm{M}$ DFO in comparison to $21 \% \mathrm{O}_{2}$ $(P \leq 0 \cdot 05)$. Significant increases in luciferase activity were observed in JEG-3 cells transfected with the pGL3-2 1 kb TTR promoter construct cultured at $1 \% \mathrm{O}_{2}$ in comparison to both $8 \%(P \leq 0 \cdot 01)$ and $21 \% \mathrm{O}_{2}(P \leq 0 \cdot 01)$. A significant increase in luciferase activity was also observed at $3 \% \mathrm{O}_{2}$ in comparison to $21 \% \mathrm{O}_{2}(P \leq 0 \cdot 05)$. This demonstrates that the TTR promoter is differentially activated under low oxygen conditions.

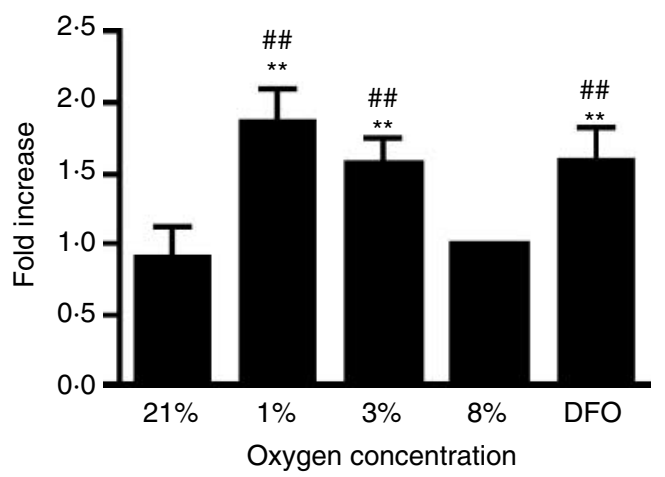

Figure $4{ }^{125}$ I-TTR uptake in primary cytotrophoblast cells cultured at different oxygen concentrations $\left(1,3,8\right.$ and $\left.21 \% \mathrm{O}_{2}\right)$ and treated with $200 \mu \mathrm{M}$ DFO. ${ }^{125}$ I-TTR uptake in the presence of $10 \mu \mathrm{M} \mathrm{T}_{4}$ significantly increased at 1 and $3 \% \mathrm{O}_{2}$ and $200 \mu \mathrm{M}$ DFO in comparison to $8 \% \mathrm{O}_{2}$. Significant increases were also observed in comparison to $21 \% \mathrm{O}_{2}$. All experiments were performed in triplicates. ${ }^{* *} P \leq 0 \cdot 01$ vs $8 \%$; ${ }^{\sharp} P \leq 0 \cdot 01$ vs $21 \%$. 
A
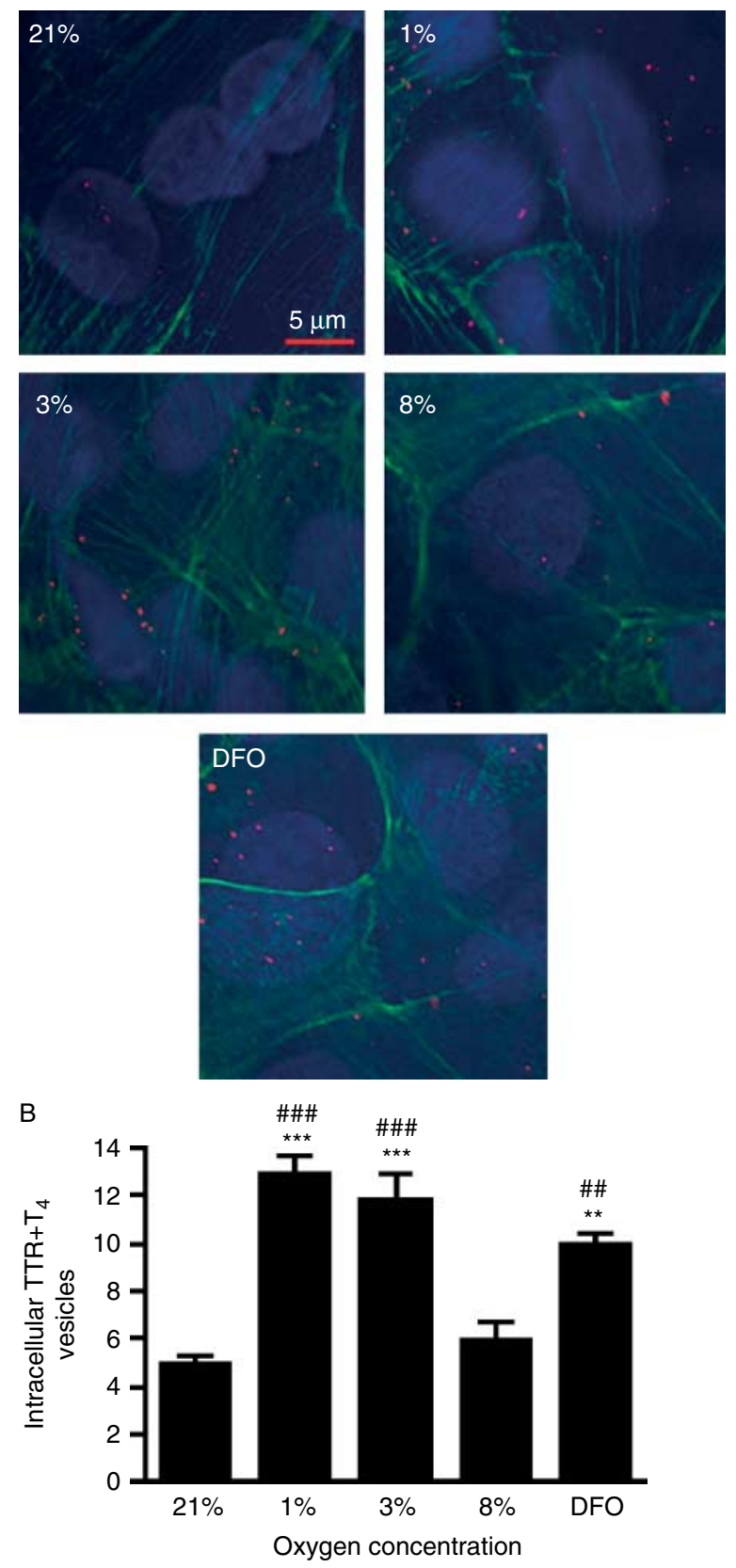

Figure 5 Alexa-594-TTR uptake quantification of TTR immunofluorescence in primary cytotrophoblast cells cultured at different oxygen concentrations $\left(1,3,8\right.$ and $\left.21 \% \mathrm{O}_{2}\right)$ and treated with $200 \mu \mathrm{M}$ DFO. (A) Alexa-594-TTR uptake in the presence of $10 \mu \mathrm{M}$ $\mathrm{T}_{4}$ increased (red foci) at 1 and $3 \%$ and with $200 \mu \mathrm{M}$ DFO in comparison to both 8 and $21 \% \mathrm{O}_{2}$. Image magnified $40 \times$ (scale bar $5 \mu \mathrm{m})$. (B) Alexa-594-TTR foci were counted in randomly selected cells $(n=30)$ to quantify internalisation. Significant increases in counted TTR foci were observed at 1 and $3 \% \mathrm{O}_{2}$ and $200 \mu \mathrm{M}$ DFO in comparison to both 8 and $21 \% \mathrm{O}_{2}$. All experiments were performed in triplicates. ${ }^{* *} P \leq 0 \cdot 01 \mathrm{vs} 8 \% ;{ }^{* * *} P \leq 0 \cdot 001$ vs $8 \%$; ${ }^{\#} P \leq 0 \cdot 01$ vs $21 \% ;{ }^{\# \#} P \leq 0 \cdot 001$ vs $21 \%$.

\section{Discussion}

Our results confirm our previous findings that the low placental oxygen levels reported in very early pregnancy may up-regulate TTR mRNA and protein levels and TTR secretion by trophoblast cells (Patel et al. 2010a). Exposure to low oxygen levels also resulted in increased cellular uptake of TTR by primary trophoblasts, validating the use of JEG-3 cells as a model for examining interactions of TTR synthesis, secretion and uptake when exposed to different oxygen levels (Patel et al. 2010a).

TTR is a $56 \mathrm{kDa}$ homotetrameric protein found in serum where it transports $\mathrm{T}_{4}$ and retinol (Blake et al. 1971, Palha 2002). TTR is produced and secreted into the circulation by liver (Hamilton \& Benson 2001). TTR secretion by fetal tissues begins very early in gestation, with TTR secretion observed in the choroid plexus by week 8 and in the fetal liver by weeks 16-20 (Jacobsson 1989). TTR is one of the three major $\mathrm{TH}$ transport proteins in serum (thyroxine-binding globulin (TBG) and albumin being the other two) and has a relatively high binding affinity for $\mathrm{T}_{4}\left(7 \cdot 0 \times 10^{7} \mathrm{M}\right)$ and a serum concentration of $\sim 4.6 \times 10^{-6} \mathrm{M}$. Approximately $15 \%$ of circulating $\mathrm{T}_{4}$ is bound to TTR (Hamilton \& Benson 2001). TTR is also synthesised and secreted by choroid plexus and is the predominant $\mathrm{T}_{4}$ binding protein in cerebrospinal fluid (CSF; Herbert et al. 1986). TTR may be involved in transfer of serum $\mathrm{T}_{4}$ to CSF and distribution of CSF $\mathrm{T}_{4}$ into brain (Schreiber et al. 1995). The retinal pigment epithelium also strongly expresses TTR and a role for $\mathrm{T}_{4}$ delivery within the eye has been proposed (Cavallaro et al. 1990). Previous work from our group has demonstrated that the human placenta is also capable of producing albumin but not TBG. However, the role of albumin, which has a low affinity but high capacity for thyroid hormone binding, within the placenta is not yet known (McKinnon et al. 2005).

A number of placental cell membrane thyroid hormone transporters have been described, including monocarboxylate transporters 8 and 10 (MCT8, MCT10); 1-amino acid transporters 1 and 2 (Lat1, Lat2); and organic anion transporting polypeptide $1 \mathrm{~A} 2$ and 4A1 (Oatp1A2, Oatp4A1), which have been postulated to mediate $\mathrm{T}_{4}$ transport (Loubiere et al. 2010). Only Lat1 has been reported to be affected (destabilised) by hypoxia (Boado et al. 2003). We hypothesize that placental TTR is involved in transport of maternal $T_{4}$ to the fetus, as a carrier of $T_{4}$ or by delivery of $\mathrm{T}_{4}$ to trophoblast $\mathrm{T}_{4}$ membrane transporters or both.

During the first trimester, the placenta and fetus are exposed to relatively hypoxic conditions; oxygen concentrations early after implantation range from 1 to $3 \%$ $(15-18 \mathrm{mmHg})$. These are optimal conditions for early placental and embryonic development (Rodesch et al. 1992, Jauniaux et al. 2000). Low oxygen levels stimulate trophoblast invasion into the maternal decidua, leading to increased uterine spiral artery remodelling and increased vascular compliance. By $8-10$ weeks gestation, oxygen concentrations rise 3-5\% 


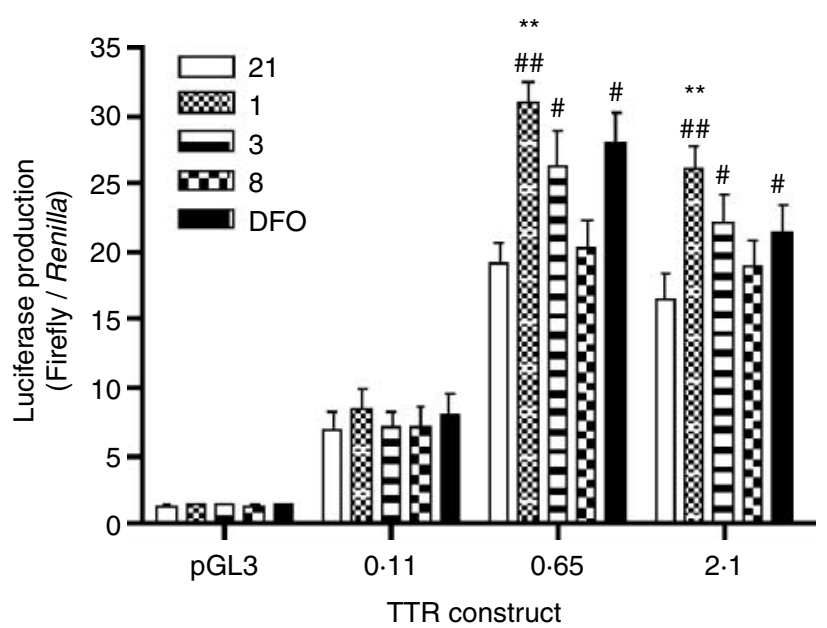

Figure 6 TTR promoter activity in JEG-3 placental cells cultured at different oxygen concentrations $\left(1,3,8\right.$ and $\left.21 \% \mathrm{O}_{2}\right)$ and treated with $200 \mu \mathrm{M}$ DFO. Three TTR promoter constructs (pGL3-0.11, pGL3-0.65 and pGL3-2.1) were transfected into JEG-3 cells and cultured for $24 \mathrm{~h}$. Luciferase activity was measured to determine promoter activity using a ratio between Firefly/Renilla luminescence. No differences were observed in cells transfected with pGL3-0.11 $(n=12)$. In cells transfected with pGL3-0.65 $(n=12)$, significant increases in luciferase activity were measured in cells cultured at $1 \% \mathrm{O}_{2}$ in comparison to 8 and $21 \% \mathrm{O}_{2}$. Significant increases were also observed in cells grown at $3 \% \mathrm{O}_{2}$ and $200 \mu \mathrm{M}$ in comparison to $21 \% \mathrm{O}_{2}$. In cells transfected with the pGL3-2.1 $(n=12)$ TTR construct, significant increase at $1 \% \mathrm{O}_{2}$ in comparison to 8 and $21 \% \mathrm{O}_{2}$ was observed. Significant increases were also observed at $3 \% \mathrm{O}_{2}$ and $200 \mu \mathrm{M}$ DFO in comparison to $21 \% \mathrm{O}_{2}$. ${ }^{* * P} \leq 0.01$ vs $8 \%$; ${ }^{\sharp} P \leq 0.05$ vs $21 \%$; ${ }^{\sharp} P \leq 0.01$ vs $21 \%$.

(18 mmHg). Towards the end of the first trimester (11-12 weeks gestation), oxygen concentrations rise 7-10\% $(60 \mathrm{mmHg})$ and remain at this level until term (Rodesch et al. 1992). These changes in placental oxygen concentrations are important for regulating trophoblast differentiation, maturation and function throughout gestation (Genbacev et al. 1997).

Before experimentation could be conducted, it is needed to be determined whether a functioning cell culture model was present. Therefore, both hCG and LDH were measured in cultured medium. hCG secretion was reduced at $1 \% \mathrm{O}_{2}$, rising slightly at $3 \% \mathrm{O}_{2}$ and $\mathrm{DFO}$ and peaking at $8 \% \mathrm{O}_{2}$. These findings are consistent with previous work in our laboratory, where hCG secretion was measured from BeWo placental cells cultured at low oxygen concentrations (Li et al. 2011). No changes in LDH secretion between the experimental groups demonstrated good cell viability, as was observed in our previous study using JEG-3 placental cells (Patel et al. 2010a).

In this study, TTR mRNA expression, protein levels and uptake of ${ }^{125}$ I-TTR and Alexa-594-TTR in cells cultured in 1 and $3 \% \mathrm{O}_{2}$ were significantly greater than in trophoblasts cultured at $8 \%$. In cells cultured at $21 \% \mathrm{O}_{2}$, TTR mRNA and protein expression and TTR uptake were increased by treatment with $200 \mu \mathrm{M}$ DFO, a hypoxia-mimicking agent. During hypoxia, HIF-1 $\alpha$ drives the transcriptional response to oxygen deprivation by binding to hypoxia response elements within the promoters or enhancers of genes involved in nutrient exchange and energy expenditure (Bunn \& Poyton 1996, Wenger \& Gassmann 1997). HIF-1 $\alpha$ activity is critical for normal placental development (Aplin 2000). We have demonstrated up-regulation of HIF- $1 \alpha$ in cells grown at 1 and $3 \% \mathrm{O}_{2}$ and in cells grown at $21 \%$ treated with DFO, suggesting that up-regulation of TTR at low oxygen concentrations may be driven by HIF- $1 \alpha$.

TTR promoter activity was also increased in JEG-3 cells cultured under low oxygen conditions, specifically in the pGL3-0.65 kb and pGL3-2.1 kb constructs. Previous work on TTR promoter function in liver cells demonstrated that a number of transcription factors must be bound for TTR expression to be activated and binding sites for these are found within the pGL3-0.65 kb and pGL3-2.1 kb constructs. These include hepatic nuclear factors 1, 3 and 4 (HNF-1, 3 and 4), CCAAT/enhancer binding protein (C/EBP) and activator protein-1 (AP-1; Fung et al. 1988, Costa \& Grayson 1991). TTR expression has been detected in multiple tissue types including the placenta, choroid plexus and yolk-sac, and coordination of these transcription factors to illicit TTR expression will differ between tissues (Costa et al. 1990, Qian et al. 1995). This is perfectly demonstrated in the liver, where during the acute-phase response, TTR expression is rapidly down-regulated (Qian et al. 1995). However, in the choroid plexus, there is no change in TTR expression under the same conditions (Costa et al. 1990). Additionally, early gestation yolk-sac production of TTR clearly occurs under hypoxic conditions and we have now also demonstrated this within placental cells, albeit in vitro. Within the placenta, HNF-3 (also known as FOXa2), C/EBP and AP-1 are found to be highly expressed throughout gestation and play a key role in activating the transcription of a number of important genes for fetal development (Bamberger et al. 2004a, 2004b, Friedman \& Kaestner 2006). It is also interesting to note that both C/EBP and AP-1 are up-regulated under hypoxic conditions and closely interact with HIF-1 $\alpha$, leading to the transcription of specific gene targets (Cummins \& Taylor 2005, Janardhan 2008). In this study, we have demonstrated increased TTR promoter activity in cells cultured under low oxygen culture conditions; however, further in-depth analysis of placental transcription factors will increase our understanding of placental specific regulation of TTR expression.

There is also a growing body of evidence to suggest that type 3 deiodinase (D3) activity is regulated by hypoxia in a tissue-specific manner (Simonides et al. 2008). D3 is highly expressed in the placenta, more so earlier in gestation to actively regulate the amount of maternal $\mathrm{T}_{4}$ being presented to the fetus (Chan et al. 2003). Therefore, we postulate that TTR binding may play a role in protecting maternal $T_{4}$ from active deiodination within the placenta, allowing greater concentrations of $\mathrm{T}_{4}$ to enter the fetal circulation, particularly 
early in gestation where $T_{4}$ is so critical for neurological development.

Oxygen appears to be an important regulator of trophoblast TTR expression in vitro. While enhancement of TTR in the early, relatively hypoxic placenta (at a time when the fetus is absolutely dependent on maternal transfer of $\mathrm{T}_{4}$ ) has teleological appeal, however, many other unknown in vivo factors undoubtedly play a role in the regulation of TTR. Therefore, this topic deserves further investigation.

\section{Conclusion}

Our study has unequivocally demonstrated up-regulation of TTR expression and TTR uptake by primary cytotrophoblast cells cultured at low oxygen concentrations. This may suggest increased transplacental delivery of $\mathrm{T}_{4}$ to the fetus during the first trimester of pregnancy.

\section{Declaration of interest}

The author declares that there is no conflict of interest that could be perceived as prejudicing the impartiality of the research reported

\section{Funding}

A University of Queensland Research Scholarship supported J P during the study.

\section{Author contribution statement}

$\mathrm{J}$ P performed the laboratory work in this study as part of his $\mathrm{PhD}$ thesis. K A L designed and prepared the TTR reporter constructs. R H M and K R supervised the project.

\section{Acknowledgements}

We would like to thank all the mothers from the Royal Brisbane and Women's Hospital who kindly agreed to the use of their placentas in our study and the midwives who assisted in this.

\section{References}

Aplin JD 2000 Hypoxia and human placental development. Journal of Clinical Investigation 105 559-560. (doi:10.1172/JCI9512)

Bamberger AM, Bamberger CM, Aupers S, Milde-Langosch K, Loning T \& Makrigiannakis A 2004a Expression pattern of the activating protein-1 family of transcription factors in the human placenta. Molecular Human Reproduction 10 223-228. (doi:10.1093/molehr/gah011)

Bamberger AM, Makrigiannakis A, Schroder M, Bamberger CM, Relakis C, Gellersen B, Milde-Langosch K \& Loning T 2004b Expression pattern of the CCAAT/enhancer-binding proteins C/EBP-alpha, C/EBP-beta and C/EBP-delta in the human placenta. Virchows Archiv 444 149-152. (doi:10.1007/s00428-003-0935-7)

Barber KJ, Franklyn JA, McCabe CJ, Khanim FL, Bulmer JN, Whitley GS \& Kilby MD 2005 The in vitro effects of triiodothyronine on epidermal growth factor-induced trophoblast function. Journal of Clinical Endocrinology and Metabolism 90 1655-1661. (doi:10.1210/jc.2004-0785)
Bernal J 2005 Thyroid hormones and brain development. Vitamins and Hormones 71 95-122.

Blake CC, Swan ID, Rerat C, Berthou J, Laurent A \& Rerat B 1971 An X-ray study of the subunit structure of prealbumin. Journal of Molecular Biology 61 217-224. (doi:10.1016/0022-2836(71)90218-X)

Boado RJ, Li JY, Tsukamoto H \& Pardridge WM 2003 Hypoxia induces de-stabilization of the LAT1 large neutral amino acid transporter mRNA in brain capillary endothelial cells. Journal of Neurochemistry 85 1037-1042. (doi:10.1046/j.1471-4159.2003.01757.x)

Bunn HF \& Poyton RO 1996 Oxygen sensing and molecular adaptation to hypoxia. Physiological Reviews 76 839-885.

Calvo R, Obregon MJ, Ruiz de Ona C, Escobar del Rey F \& Morreale de Escobar G 1990 Congenital hypothyroidism, as studied in rats. Crucial role of maternal thyroxine but not of $3,5,3^{\prime}$-triiodothyronine in the protection of the fetal brain. Journal of Clinical Investigation 86 889-899. (doi:10.1172/ JCI114790)

Cavallaro T, Martone RL, Dwork AJ, Schon EA \& Herbert J 1990 The retinal pigment epithelium is the unique site of transthyretin synthesis in the rat eye. Investigative Ophthalmology \& Visual Science 31 497-501.

Chan S, Kachilele S, Hobbs E, Bulmer JN, Boelaert K, McCabe CJ, Driver PM, Bradwell AR, Kester M, Visser TJ et al. 2003 Placental iodothyronine deiodinase expression in normal and growth-restricted human pregnancies. Journal of Clinical Endocrinology and Metabolism 88 4488-4495. (doi:10.1210/jc.2003-030228)

Chu PW, Beart PM \& Jones NM 2010 Preconditioning protects against oxidative injury involving hypoxia-inducible factor-1 and vascular endothelial growth factor in cultured astrocytes. European Journal of Pharmacology 633 24-32. (doi:10.1016/j.ejphar.2010.02.008)

Costa RH \& Grayson DR 1991 Site-directed mutagenesis of hepatocyte nuclear factor (HNF) binding sites in the mouse transthyretin (TTR) promoter reveal synergistic interactions with its enhancer region. Nucleic Acids Research 19 4139-4145. (doi:10.1093/nar/19.15.4139)

Costa RH, Van Dyke TA, Yan C, Kuo F \& Darnell JE Jr 1990 Similarities in transthyretin gene expression and differences in transcription factors: liver and yolk sac compared to choroid plexus. PNAS 87 6589-6593. (doi:10. 1073/pnas.87.17.6589)

Cummins EP \& Taylor CT 2005 Hypoxia-responsive transcription factors. Pflügers Archiv: European Journal of Physiology 450 363-371. (doi:10.1007/ s00424-005-1413-7)

Divino CM \& Schussler GC 1990 Receptor-mediated uptake and internalization of transthyretin. Journal of Biological Chemistry 265 1425-1429.

Friedman JR \& Kaestner KH 2006 The Foxa family of transcription factors in development and metabolism. Cellular and Molecular Life Sciences 63 2317-2328. (doi:10.1007/s00018-006-6095-6)

Fung WP, Thomas T, Dickson PW, Aldred AR, Milland J, Dziadek M, Power B , Hudson P \& Schreiber G 1988 Structure and expression of the rat transthyretin (prealbumin) gene. Journal of Biological Chemistry 263 480-488.

Genbacev O, Zhou Y, Ludlow JW \& Fisher SJ 1997 Regulation of human placental development by oxygen tension. Science 277 1669-1672. (doi:10.1126/science.277.5332.1669)

Greenwood FC, Hunter WM \& Glover JS 1963 The preparation of I-131labelled human growth hormone of high specific radioactivity. Biochemical Journal 89 114-123.

Greenwood SL, Clarson LH, Sides MK \& Sibley CP 1996 Membrane potential difference and intracellular cation concentrations in human placental trophoblast cells in culture. Journal of Physiology 492 629-640.

Haddow JE, Palomaki GE, Allan WC, Williams JR, Knight GJ, Gagnon J, O'Heir CE, Mitchell ML, Hermos RJ, Waisbren SE et al. 1999 Maternal thyroid deficiency during pregnancy and subsequent neuropsychological development of the child. New England Journal of Medicine 341 549-555. (doi:10.1056/NEJM199908193410801)

Hamilton JA \& Benson MD 2001 Transthyretin: a review from a structural perspective. Cellular and Molecular Life Sciences 58 1491-1521. (doi:10.1007/ PL00000791)

Herbert J, Wilcox JN, Pham KT, Fremeau RT Jr, Zeviani M, Dwork A, Soprano DR, Makover A, Goodman DS, Zimmerman EA et al. 1986 Transthyretin: a choroid plexus-specific transport protein in human brain. The 1986 S. Weir Mitchell award. Neurology 36 900-911. 
Jacobsson B 1989 In situ localization of transthyretin-mRNA in the adult human liver, choroid plexus and pancreatic islets and in endocrine tumours of the pancreas and gut. Histochemistry 91 299-304. (doi:10.1007/BF00493004)

Janardhan HP 2008 The HIF-1 alpha-C/EBP alpha axis. Science Signaling 1 jc2. (doi:10.1126/scisignal.143jc2)

Jauniaux E, Watson AL, Hempstock J, Bao YP, Skepper JN \& Burton GJ 2000 Onset of maternal arterial blood flow and placental oxidative stress. A possible factor in human early pregnancy failure. American Journal of Pathology 157 2111-2122. (doi:10.1016/S0002-9440(10)64849-3)

Klausner RD, Donaldson JG \& Lippincott-Schwartz J 1992 Brefeldin A: insights into the control of membrane traffic and organelle structure. Journal of Cell Biology 116 1071-1080. (doi:10.1083/jcb.116.5.1071)

Kliman HJ, Nestler JE, Sermasi E, Sanger JM \& Strauss JF III 1986 Purification, characterization, and in vitro differentiation of cytotrophoblasts from human term placentae. Endocrinology 118 1567-1582. (doi:10.1210/ endo-118-4-1567)

Landers KA, McKinnon BD, Li H, Subramaniam VN, Mortimer RH \& Richard K 2009 Carrier-mediated thyroid hormone transport into placenta by placental transthyretin. Journal of Clinical Endocrinology and Metabolism 94 2610-2616. (doi:10.1210/jc.2009-0048)

Li H, Landers K, Patel J, Richard K \& Mortimer RH 2011 Effect of oxygen concentrations on sodium iodide symporter expression and iodide uptake and hCG expression in human choriocarcinoma BeWo cells. American Journal of Physiology. Endocrinology and Metabolism 300 E1085-E1091. (doi:10.1152/ajpendo.00679.2010)

Loubiere LS, Vasilopoulou E, Bulmer JN, Taylor PM, Stieger B, Verrey F, McCabe CJ, Franklyn JA, Kilby MD \& Chan SY 2010 Expression of thyroid hormone transporters in the human placenta and changes associated with intrauterine growth restriction. Placenta 31 295-304. (doi:10.1016/ j.placenta.2010.01.013)

McKinnon B, Li H, Richard K \& Mortimer R 2005 Synthesis of thyroid hormone binding proteins transthyretin and albumin by human trophoblast. Journal of Clinical Endocrinology and Metabolism $906714-6720$. (doi:10.1210/jc.2005-0696)

Mirkovitch J \& Darnell JE Jr 1991 Rapid in vivo footprinting technique identifies proteins bound to the TTR gene in the mouse liver. Genes and Development 5 83-93. (doi:10.1101/gad.5.1.83)

Obregon MJ, Calvo RM, Del Rey FE \& de Escobar GM 2007 Ontogenesis of thyroid function and interactions with maternal function. Endocrine Development 10 86-98.

Palha JA 2002 Transthyretin as a thyroid hormone carrier: function revisited. Clinical Chemistry and Laboratory Medicine 40 1292-1300. (doi:10.1515/ CCLM.2002.223)

Patel J, Landers K, Li H, Mortimer RH \& Richard K 2010a Oxygen concentration regulates expression and uptake of transthyretin, a thyroxine binding protein, in JEG-3 choriocarcinoma cells. Placenta 32 128-133. (doi:10.1016/j.placenta.2010.11.016)

Patel J, Landers K, Mortimer RH \& Richard K $2010 b$ Regulation of hypoxia inducible factors (HIF) in hypoxia and normoxia during placental development. Placenta 31 951-957. (doi:10.1016/j.placenta.2010.08.008)
Patel J, Landers K, Li H, Mortimer RH \& Richard K 2011a Delivery of maternal thyroid hormones to the fetus. Trends in Endocrinology and Metabolism 22 164-170. (doi:10.1016/j.tem.2011.02.002)

Patel J, Landers K, Li H, Mortimer RH \& Richard K $2011 b$ Thyroid hormones and fetal neurological development. Journal of Endocrinology 209 1-8. (doi:10.1530/JOE-10-0444)

Pfaffl MW, Horgan GW \& Dempfle L 2002 Relative expression software tool (REST) for group-wise comparison and statistical analysis of relative expression results in real-time PCR. Nucleic Acids Research 30 e36. (doi:10.1093/nar/30.9.e36)

Qian X, Samadani U, Porcella A \& Costa RH 1995 Decreased expression of hepatocyte nuclear factor 3 alpha during the acute-phase response influences transthyretin gene transcription. Molecular and Cellular Biology 15 1364-1376.

Ran R, Xu H, Lu A, Bernaudin M \& Sharp FR 2005 Hypoxia preconditioning in the brain. Developmental Neuroscience 27 87-92. (doi:10. 1159/000085979)

Rodesch F, Simon P, Donner C \& Jauniaux E 1992 Oxygen measurements in endometrial and trophoblastic tissues during early pregnancy. Obstetrics and Gynecology 80 283-285.

Schneider H 2011 Oxygenation of the placental-fetal unit in humans. Respiratory Physiology \& Neurobiology 178 51-58. (doi:10.1016/j.resp.2011. 05.009)

Schreiber G, Southwell BR \& Richardson SJ 1995 Hormone delivery systems to the brain-transthyretin. Experimental and Clinical Endocrinology E Diabetes 103 75-80. (doi:10.1055/s-0029-1211332)

Simonides WS, Mulcahey MA, Redout EM, Muller A, Zuidwijk MJ, Visser TJ, Wassen FW, Crescenzi A, da-Silva WS, Harney J et al. 2008 Hypoxia-inducible factor induces local thyroid hormone inactivation during hypoxic-ischemic disease in rats. Journal of Clinical Investigation 118 975-983.

Takeda T, Sakata M, Isobe A, Yamamoto T, Nishimoto F, Minekawa R, Okamoto Y, Tasaka K \& Murata Y 2007 Hypoxia represses the differentiation of R cho-1 rat trophoblast giant cells. Gynecologic and Obstetric Investigation 63 188-194. (doi:10.1159/000097634)

Vulsma T, Gons MH \& de Vijlder JJ 1989 Maternal-fetal transfer of thyroxine in congenital hypothyroidism due to a total organification defect or thyroid agenesis. New England Journal of Medicine 321 13-16. (doi:10.1056/ NEJM198907063210103)

Wenger RH \& Gassmann M 1997 Oxygen(es) and the hypoxia-inducible factor-1. Biological Chemistry 378 609-616.

\section{Received in final form 13 October 2011}

Accepted 1 November 2011

Made available online as an Accepted Preprint 1 November 2011 